\title{
Christian Ethics and Spirituality in Leading Business Organizations: Editorial Introduction
}

\author{
Domènec Melé $^{1} \cdot$ Joan Fontrodona ${ }^{1}$
}

Received: 4 August 2016/Accepted: 30 August 2016/Published online: 9 September 2016

(C) Springer Science+Business Media Dordrecht 2016

\begin{abstract}
Christian ethics applied to economics and business has a long tradition. This dates back at least to the thirteenth century, with noteworthy developments in the four following centuries and again in the last century. Christian faith and reason intertwine to bring about principles, criteria, and guidelines for action and a set of virtues with relevance for economic activity. Christian spirituality, with 2000 years of history, has been embedded in Christianity from its beginning, but the application to modern business activity is relatively recent. This article introduces a special issue which, we hope, will make its own small contribution to the developments of both Christian ethics and spirituality in the leading business organizations. After a short historical overview and a consideration of the current situation of Christian ethics and spirituality in business, we introduce the papers selected for this issue.
\end{abstract}

Keywords Business ethics - Catholic social teaching Christian ethics $\cdot$ Christian spirituality $\cdot$ Common good . Leadership

Domènec Melé

mele@iese.edu

Joan Fontrodona

fontrodona@iese.edu

1 IESE Business School, University of Navarra, Barcelona, Spain
I urge you to draw upon these great human and moral resources and to take up this challenge with determination and far-sightedness. Without ignoring, naturally, the specific scientific and professional requirements of every context, I ask you to ensure that humanity is served by wealth and not ruled by it.

Pope Francis, Letter to the Executive Chairman of the World Economic Forum, 2014.

With these words, Pope Francis encourages us to strive for what is at the core of business ethics. A great challenge was also proclaimed by other moral voices. Saying that "ensuring that humanity is served by wealth and not ruled by it" is a permanent Christian request which originates in the Gospel: "you cannot serve God and Wealth," said Jesus (Bible, Matthew 6:24). This sentence is not a pejorative vision of business, only a way to situate business and economic activity in the right place, stressing that wealth is instrumental and should serve to higher human ends.

Using economic wealth as a means to higher human ends is not the only Christian principle for business. Actually, Christianity, as well as other religions, entails many ethical criteria for business and encourages virtues. Similarly, Christian spirituality can be inspirational in leading business.

As we will see below, Christian ethics in economics and business has a long tradition but still needs future developments. Christian spirituality, with 2000 years of history, has been embedded in Christianity from its beginning, but the application to modern business activity is relatively recent and academic research is still incipient. This double need led to the choice of Christian Ethics and Spirituality in Leading Organizations as the theme of the 4th International Colloquium on Christian Humanism in Economic and Business held by IESE Business School (Barcelona, April 20-21, 2015). Here, after a long process of selection 
and revision, we are proud to introduce this special issue with a selection of papers presented at this conference.

\section{Christian Ethics and Spirituality}

Although there are diverse approaches to Christian ethics (Crook 2002, pp. 28ff; Gill 2001), generally they have in common that they take the teachings of Jesus of Nazareth (Christ) and the Apostles contained in the Christian Bible (Old and New Testaments) as the main source for its developments, along with the living Christian Tradition and some outstanding developments of Jesus' followers (Melé 2008). Within the Catholic Church, the Magisterium, or teachings of the Pope and Bishops in communion with the Pope (Ratzinger 1975), is highly relevant. This provides an authoritative interpretation of biblical revelation and the Christian Tradition. This teaching considers too the changing circumstances of social reality. In Christian ethics, the double commandment of love (agape, in Greek)love to God and neighbor-and the imitation of Jesus' love are central (Melé 2012a), but other virtues, principles and norms are also relevant Melé (2016).

The intertwining of Christian faith and reason give us Christian moral theology (see an introduction in May 2003 or Cessario 2013), which has been briefly defined as "a science which accepts and examines Divine revelation while at the same time responding to the demands of human reason.'(John Paul II, 1993, n. 29). Moral theology is a reflection concerned with 'morality', with the good and the evil of human acts and of the person who performs them; in this sense it is accessible to all people (Ibidem). Responding to the demands of human reason, moral theology entails internal logic and reasonability, making it significant for constructive dialogue with other positions.

Christian ethics has been developed over 2000 years (Wogaman 1993) from the Bible (1966) and from several philosophical legacies (Pinckaers 1995), firstly with seminal thinkers (from the second to fourth centuries) and then with the exceptional figure of St. Augustin of Hippo in the fifth century. In the Middle Ages, Scholasticism emerged as a theological and philosophical school of thought, with another giant, Thomas Aquinas (thirteenth century). He developed Christian ethics by using Aristotelian ethics as intellectual support, although he gave primacy to love (Wadell 1991). Aquinas' great intellectual synthesis had a remarkable influence for centuries and even now this remains in several contemporaneous Neo-Thomists, such as Gilson and Maritain.

In the sixteenth century, the prominent reformers Martin Luther and John Calvin recovered some insights from St. Augustin for a renewed view of Christian Ethics. On their part, Catholics following Aquinas primarily developed a body of knowledge which enriched the patrimony of Christian ethics, especially in applied areas such as politics and economics in a stream of thought generally known as Late-Scholasticism. The School of Salamanca, in Spain, in the sixteenth and seventeenth centuries, is of special note. After some centuries of decadence, save for Alphonsus Liguori in the eighteenth century, Christian ethics emerged again in the twentieth century, through several Christian moral thinkers, Papal social encyclical letters, the Social Gospel Movement, the Vatican Council II, and what was termed ecumenical social ethics (Wogaman 1993, pp. 191ff).

The relevance of Christian ethics is clear if we consider that there are some 2 billion followers worldwide, although they may have different degrees of adherence and their interpretations vary on some points. Moreover, Christian ethics has had a practical influence on philosophers and even on ordinary people in many historical periods, opening new horizons to them. As Pope John Paul II wrote, "the word of God leaves philosophy enriched, because reason discovers new and unsuspected horizons" (John Paul II 1998, n. 73). That does not mean that philosophy depends on faith, but faith opens new prospects for reflection. In fact, in the Bible-the crucial source of Christian ethics, as noted above-we find significant concepts now widely used in ethics and business ethics, for example the concept of "human dignity," adopted by several secular ethical systems and included in the Preamble of the UN Universal Declarations of the Human Rights, n. 32. Novak (1998) argues that "human dignity," although this expression was coined in the Renaissance, has JudeoChristian roots, since the first book of the Bible states that the human being - both male and female-was created to "image of God" (Bible, Genesis 1:27). This gives to every human individual (person) a great dignity and serves as a good foundation for universal human rights.

Human rights are also implicit in the Ten Commandments or Decalogue (Bible, Exodus 20:1-17; Deuteronomy 5:6-22), shared by Jews and Christians. These express a set of moral duties, some of which involve respect for human rights. As the Catholic Church teaches: "The Ten Commandments are part of God's Revelation. At the same time, they teach us man's true humanity. They shed light on the essential duties, and so indirectly on the fundamental rights, inherent in the nature of the human person" (Catechism of the Catholic Church 2003, n. 2070).

Another concept often invocated in business ethics is the "Golden Rule." Jesus enunciated it in these terms: "Do to others as you would have them to do to you" (Bible, Luke 6:27; Matthew 7:12). This rule requires benevolence toward others, in contrast with the so-called "Silver Rule" ("do unto others as they do unto you"), proposed by other sources, which only focus on reciprocity (Tullberg 2012). 
The notion of "stewardship" with natural resources or "environmental stewardship" is also found in the Bible in connection with the second narration of the Creation (Bible, Genesis, Chapter 2). We read that at the beginning, "The Lord God took the man and put him in the Garden of Eden to till it and keep it" (Bible, Genesis 2:15). According to Pope Francis, "tilling" refers to cultivating, ploughing, or working, while "keeping" means caring for, protecting, overseeing, and preserving, and "this implies a relationship of mutual responsibility between human beings and nature" (Francis 2015, n. 67). Therefore, 'our 'dominion' over the universe should be understood more properly in the sense of responsible stewardship" (Francis 2015, n. 116). Enderle (1997), who accepts the biblical roots of "environmental stewardship," thinks that this concept can contribute to the "common ground" of environmental responsibility.

The Gospel emphasizes the idea of service in leading others. Jesus said: "whoever wishes to be the great come great among you must be your servant, and whoever wishes to be first among you must be your slave; just as the Son of Man came not to be served, but to serve" (Bible, Matthew 20:27-28). These words promoted throughout the ages by Jesus' followers are at the root of the concept of "servant leadership," introduced by Robert Greenleaf (1970) and now a recognized theory of leadership. This theory accentuates developing members of the organization, empowering them to serve, and demonstrating that serving others spurs followers onto virtuous behavior. Although Greenleaf (1977) conceptualized the servant as a leader from his impressions of the novel Journey to the East by Hesse, and used the behavior of one of its characters (Leo), many scholars see Jesus Christ's teachings to his disciples as the ultimate example of servant leadership (e.g., Parris and Peachey 2013, p. 379).

It is worth noting that Christian spirituality, in contrast to other ideologically-based spiritualities, is theologicalbased spirituality (Aumann 1985). Christian spirituality has a great richness of concepts (Scorgie et al. 2011), approaches, and definitions (Scheiders 1989). Through the ages, religious life or interior life and spirituality were taken as being practically synonymous. Nowadays, spirituality is generally defined independently of religion, although religion, and in particular the Christian religion, entails spirituality. "Spirituality" comes from the Hebrew word ruach (spirit, breath, wind), which can be interpreted as that which gives life and animation to something. According to McGrath (1999), spirituality is that which animates a person's life of faith and moves a person's faith to greater depths and perfection. It is a way of life which entails beliefs and values related with an ultimate concern. For Christians, the ultimate concern is God revealed in Jesus Christ, and Christian spirituality requires fellowship of Christ and living in Christ through the gift of the Holy
Spirit. Spirituality involves the whole person (body, mind, soul, relationships), the entire fabric of our lives; it is a lived experience and involves experiencing and knowing God (not just knowing about God).

\section{Christian Ethics in Economics and Business}

Christian ethics applied to social-economic life started with the very beginning of Christianity, as a renewed continuation of Jewish morals, in both intellectual developments and practice (Charles 1998). Over time, a number of Christian thinkers have made significant contributions on ethics in business centuries before the current movement of business ethics, particularly from the thirteenth century (Melé 2013; Schlag 2013). In the sixteenth century, theologians of the School of Salamanca, such as Francisco de Vitoria and Bartolome de las Casas made a strong defense of universal human rights (Hoffmann-Holland 2009) with implications for labor. Some authors of this school actively worked on moral issues of business and finance, such as how to do business in accordance with Christian ethics. They generally followed Thomas Aquinas, who included the Moral Natural Law-accessible to reason at least its basic principles-within a moral system based on virtues. Scholastic doctrine included morality on contracts, financial transaction, just price and market morality, and others (Chafuen 1986; Melé 1999, 2016; Azevedo Alves and Moreira 2010, 2013).

Scholasticism is still alive and can make significant contributions to the business ethics field ${ }^{1}$. In this issue, Lamberto Zollo, Massimiliano M. Pellegrini, and Cristiano Ciappei go back to Scholastic thought and discuss the interplay between moral intuition and moral reasoning in decision-making. They argue that nowadays the traditional rationalist framework of ethical decision-making has been challenged by recent psychological and managerial literature, which stresses the importance of unconscious elements of decision makers' cognition, such as intuition and emotions. They interpret moral intuition as an antecedent of the ethical decision-making process, to be blended with the traditional moral reasoning or the deliberative and intentional process. In particular, they use the Scholastic concept of synderesis, defined by Aquinas as "the law of our intellect insofar as it is the habit that contains the precepts of natural law, that is, the first principles of human actions" (1981[1273], I-II, q. 94, a. 2). This innate human faculty constantly inclines decision makers toward the discovery of the human good and consequently to universal moral principles. The authors

\footnotetext{
${ }_{1}$ The Handbook of the Philosophical Foundations of Business Ethics (Lüetge 2008) includes a section on Scholasticism.
} 
integrate synderesis into a framework that attempts to combine the intuitionist and rationalist perspectives with virtue ethics and then apply the result to ethical decisionmaking.

Related with Scholasticism also, a second paper, authored by Grant Michelson and Sandrine Fremeaux, analyzes two emerging models of business through the lenses of the common good-a central concept in Scholasticism with Aristotelian roots-and humanistic management: Conscious Capitalism and the Economy of Communion. The authors try to show how the pursuit of the common good of the firm can serve as a guide for humanistic management through two principles: first, community good is a condition for the realization of personal good; and second community good can only be promoted if it is oriented toward personal good. They argue that both Conscious Capitalism and Economy of Communion strive to participate in the common good, although they differ in their respective manners of linking community good and personal good.

In the twentieth century, Christian Churches, and particularly the Roman Catholic Church, have championed many relevant moral issues connected to business ethics. A personalistic view of work within the organization and some labor rights were defended by Pope Leo XIII (1891). More recently, the Catholic Church Magisterium has promoted other significant insights and has formulated principles for reflection, criteria for judgment, and guidelines for action. From the fundamental commandment of love and natural law, CST energetically defends human dignity, innate human rights, integral human development, and the relevance of the common good as a reference for moral legitimacy of the social order (John XXIII 1963; PCJP 2004; Benedict XVI 2009, nos. 1-19).

In addition, CST has pioneered a number of relevant concepts, some of which are now patrimony of business ethics. Among these, we find the consideration of business as a community (John XXIII 1961, n. 91; John Paul II 1991, nos. $32,35,43)$, the common good as criterion for legitimization of business and the market (John Paul II 1991, n. 32, 35, 43; Benedict XVI 2009, n. 36), the principle of subsidiarity (Pius XI 1931, nos.184-6; John Paul II 1991 , n. 48), the centrality of human development beyond economic development (Paul VI 1967, n. 14) and "integral human development" (Paul VI 1967, n. 14; Benedict XVI 2009), the education of consumers in the responsible use of their power of choice (John Paul II 1991, n. 36), the principle of gratuity in business (Benedict XVI 2009, nos. 34, 36), and business as a noble vocation (Francis 2015, n. 129; PCJP 2012). More recently, Pope Francis has introduced concepts such as our "common home" (Francis 2015, n. 1) by referring to our planet, the concept of "integral ecology" (Francis 2015, n. 132), and stressed the ideas of responsible stewardship over nature (Benedict XVI 2009, n. 50; Francis 2015, n. 116) and sustainability (Benedict XVI 2009, nos. 27, 40; Francis 2015, nos. 50, 207).

This issue contains three papers that establish a dialogue between CST and theoretical and practical approaches to business management. This dialogue opens horizons to improving theories and practices. Thus, Martijn Cremers argues that three pillars of Catholic Social Teaching-human dignity, solidarity, and subsidiarity - can help in rethinking corporate governance and even provide an alternative to "standard" agency theory. $\mathrm{He}$ finds this mainstream management theory problematic due to both economic limitations (asymmetric information, contract completeness, and the need for coordination through explicit power or hierarchies) and human limitations (bounded rationality, opportunism, and behaviorism). Cremers argues that these three pillars can affect three functions of corporate governance: the compass function, providing the set of values to guide the firm's strategy toward its contributions to human flourishing; the commitment function, which involves the coordination (the 'binding') toward cooperation with all stakeholders in solidarity; and the criteria function, which defines what constitutes excellence in the firm's practice both regarding external markets and internal performance.

On his part, Horacio E. Rousseau shows how establishing a dialogue between the ethical perspectives of CST on environmental ethics and the managerial view of the natural-resource-based view of the firm (NRBV) raises new possibilities for studying the complex, multi-dimensional process of corporate sustainability. In particular, he proposes integrating CST in this latter approach by considering the importance of CST in developing executive moral competences, which include moral sensitivity, moral cognition, and motivation for ecology and sustainability. These moral competences, in turn, influence the organizational selection of environmental strategies, giving leaders the intrinsic motivation to promote both a longer-term stance on corporate sustainability efforts and a relentless search for greener business models.

Finally, a paper written by Bénédicte de Peyrelongue, Olivier Masclef, Catherine Gbedolo, and Valérie Guillard focuses on "gratuitous giving" as a relevant concept anchored in CST, and ultimately in Christian love, to rethink consumer behavior. They argue that "gratuitous giving" is not only a normative matter. On the contrary, gift exchange theory, based on the circular relation of "givingreceiving-returning," remains insufficient to explain all of the gift-giving behaviors of consumers. This is due to an exaggerated focus of the mainstream theories on individual behavior and reactions motivated by material satisfaction, without considering that the person is able to act gratuitously on his or her own account, without regard to 
stimuli. They suggest that we need a more complete anthropological perspective and highlight the importance of considering gratuitousness in all business activities, including marketing. This does not mean abandoning the conventional exchange based on justice, but extending it with gratuity. According to the authors, gratuitous giving is not only a valid theory to explain consumer behaviors, but also an argument for adopting a more realistic anthropology to conceptualize the consumer as a person. This offers a new way to understand consumer behavior and opens a new avenue of inquiry into the field of gift marketing research.

These three papers are aligned with other works which have taken the Christian-or more precisely, Catholicperspective to analyze or develop some aspects of economic and business ethics. Among these works, there are some related to the economic system and marketplace (Hill and Downers 1997; Jones 1997; Bayer 1999; Longenecker et al. 2004; McDaniel 2011; Gustafson 2013) and business (Magill 1992; Child 1995; Elegido 2003; Kim et al. 2009; Bay et al. 2010; Abela 2014). Others, more specifically, refer to the theory of the firm and the purpose of business (Naughton et al. 1995; Abela 2001; Cortright and Naughton 2002; Lower 2008), to the nature of the firm (Naughton 2006; Melé 2012b), virtues in business (Naughton and Cornwall 2006), and how to manage business from the Christian faith from a theoretical perspective (Naughton 1992; Alford and Naughton 2001), or through case studies (Ibrahim et al. 1991; Lee et al. 2003; Demuijnck 2009; Naughton and Specht 2011). Some works focus on particular aspects of business ethics, such as finances (Booth 2009), environmental (Attfield 2001; Hoffman and Sandelands 2005), marketing (Abela and Murphy 2008), entrepreneurship (Cornwall and Naughton 2003; Naughton and Cornwall 2006, 2009), subsidiarity in business (Melé 2005; Naughton et al. 2015), gratuity in business (Faldetta 2011; McCann 2011; Grassl and Habisch 2011), ethical decision-making (Jackson 2004), and validation of a measure of Judeo-Christian religions in the workplace (Lynn et al. 2009). In addition, several scholars have published collective works (Melé and Dierksmeier 2012; Melé and Schlag 2015) and special issues (Journal of Business Ethics, vol 7, n. 6, 1988; vol 12, n. 12, 1993; vol. 100, supl. no. 1, 2011; Business Ethics Quarterly, vol. 7, n. 2, 1997; Journal of Management Development vol. 29, nos. 7-8, 2010).

\section{Christian Spirituality in Leading Business}

Christian spirituality in leading business has been developed to a lesser degree than Christian ethics and specific bibliography on Christian spirituality in business is still scarce. Among the exceptions, we can mention Delbecq
(1999) and de Woot (2013). Also noteworthy are several contributions regarding Christian spirituality on human work and sanctification of work (Wyszynski 1995; John Paul II 1981, Chap. 5; Illanes 2003) with implications for business. However, concepts now widely developed such as spiritual leadership (e.g., Fry 2003) and workplace spirituality (e.g., Giacalone and Jurkiewicz 2003) can be considered from the perspective of Christian spirituality.

The final four papers of this special issue are related to Christian spirituality in leading business organizations. Chris Mabey, Mervyn Conroy, Karen Blakeley, and Sara de Marco start by criticizing generic spiritual literature, particularly conventional spiritual approaches to work and spiritual leadership theory, by arguing that they are instrumental and ahistorical in nature. According to these authors, in order to exhibit ethical leadership, it is beneficial to cultivate a personal spirituality (the moral manager) which provides philosophical, emotional, and spiritual sustenance to ethical leadership in practice, without which ethical leadership is more likely to succumb to situational pressures. They propose Christian spirituality, arguing that Jesus offers a vital foundation to the practice of ethical leadership and business ethics in organizations. They also address two thorny issues which face leaders: dealing with ego and closing the gap between what we say and what we do and argue that the more we understand about the dynamics of human nature, the more we learn about the profundity of Jesus' teachings.

Christian spirituality is central in the article written by Lloyd Sandelands. He focuses on the new field of business scholarship called positive organizational scholarship (POS) (Cameron 2003; Cameron and Spreitzer 2012), which emerged at the beginning of this century at the University of Michigan and is receiving increasing admiration. According to Cameron et al., POS "is primarily concerned with the study of especially positive outcomes, processes, and attributes of organizations and their members... [it] does not represent a single theory, but it focuses on dynamics that are typically described by words such as excellence, thriving, flourishing, abundance, resilience, or virtuousness, ... [and it] is distinguished from traditional organizational studies in that it seeks to understand what represents and approaches the best of the human condition" (Cameron 2003, p. 4). Sandelands asked himself why such admiration is expressed for POS when cannot be accounted for scientifically. It is what our hearts desire but our science cannot say. He argues that the attraction to the real mystery of positive business - unified for "the best of the human condition"-is its incomprehensible and unspeakable divinity. In POS, literature lacks the right words "because it comes to the human being in business as a science attuned to its objects rather than as a religion attuned to its spirit." The author proposes that when business is positively 
human it invites us to be as Christ, to be a fully human person in joyful communion with others in God.

Within Christian spirituality, there are many sub-spiritualities, which stress some determinate aspects. In particular, within the Catholic tradition there is a variety of schools of spirituality (Aumann 1985), and so too within the Protestant tradition (Alexander 1989). The last three papers of this issue are based on two great masters of Christian-Catholic spirituality: St. Benedict and St. Ignatius of Loyola.

Guillaume Mercier and Ghislain Deslandes present a conceptual study and an empirical research conducted in several monasteries living under the Rule of St. Benedict and the corresponding spirituality. They explored how monks interpret St. Benedict's Rule-written in the sixth century AD and still used today-and found that the monks adapted the Rule to changing situations for the common good. They used both hermeneutic and ethical criteria to make this rule a way of life and treat it as a dynamic framework that helps them to follow their purpose within their organization. From the findings, these scholars learn that Benedictine monasteries offer an alternative model for practicing codes of ethics, in a virtue-ethical manner, beyond mere compliance with the text.

Josep M. Lozano focuses on St. Ignatius' spirituality and more specifically on his spiritual exercises, asking whether these can contribute to the current debate on business education. He argues that developing leadership is not a technical matter, rather such development is impossible without a personal process that develops the person's capacity for perception, learning, internalization, explicit sense-making, and constructing meaning. For this reason, he proposes an anthropological and non-denominational reading of some of the fundamental meditations found in the spiritual exercises of St. Ignatius, which can be used as a heuristic in the debate regarding what business schools propose. Last, but not least, Teresa J. Rothausen also considers St. Ignatius' spirituality and presents an approach to building a spiritual leader development practice based on six categories of interdependent developmental activities.

\section{Conclusions and Further Developments}

Besides the relevance of Christian ethics for Christian believers, a number of Christian thinkers have made significant contributions on ethics in business and economics, not only recently but over many centuries. Christian churches, particularly the Roman Catholic Church, and individual scholars, have led the discussion around relevant moral issues connected to business ethics. Moreover, important concepts widely used in business ethics either have their roots in or have received close attention within the Christian tradition.

As we have noted, an increasing interest in Christian ethics and spirituality in business and management has led recently to a number of initiatives and interest groups, conferences, and publications. This special issue is aligned with this revival.

Many "movements and programs have been developed in an effort to take more seriously the moral and spiritual life in relation to business" (PCJP 2012, n. 25). Nevertheless, and in spite of the work done, more research is necessary to develop the potentiality of Christian ethics and spirituality in business.

There are a number of areas for further research on the topic of Christian ethics and spirituality in leading business. The papers presented here belong to three of them: a) Scholasticism as philosophical basis for business ethics, b) integration of Catholic social teaching into business and management, and c) Christian spiritualities as inspirational sources for leading organizations. On this latter point, Christian leaders, such as Pope Francis, insist on "the rich heritage of Christian spirituality, the fruit of twenty centuries of personal and communal experience, has a precious contribution to make to the renewal of humanity" (Francis 2015, n. 216).

Some other points for a research agenda can be added to the previous. One is undertaking comparative studies and a sincere dialogue between economic and Christian-based ethical perspectives, trying to overcome the radical separation between both approaches. Probably, both perspectives would benefit from this dialogue. Another is re-thinking management theories and approaches from Christian ethics and the philosophical anthropology provided by the Christian perspective. In this regard, it has been affirmed that the Catholic Church "has wisely reflected within her own tradition of faith and has been able to provide an ever more accurate foundation" (PCJP 2004, n. 160) providing socio-ethical principles, including the inviolable dignity of the human person, the common good principle, and the principles of solidarity and subsidiarity (Ibid). It is necessary to investigate how these Christian principles, and their founding values, can be successfully translated into business and management.

The examination of these principles and their application to business could open up dialogue with other spiritual, religious, and philosophical traditions, which would constitute an interesting matter for research and even a way to contribute to a better understanding between civilizations.

Another point for research regards the implementation of Christian values and principles and the corresponding performance. Pope John Paul II acknowledged that the Catholic Church's "social message will gain credibility more immediately from the witness of actions than as a 
result of its internal logic and consistency" (1991, n. 57). This could be extended, of course, to other Christian perspectives. Related with this, it would also be interesting to promote studies on Christian-based best practices, as well as how Christian business leaders think and act in managing a business. Interviews with business leaders and studies of their biographies can provide role models beyond theoretical approaches.

Finally, research is suggested into how to integrate a Christian perspective in business education, considering that too often "business students are informed by powerful theories and highly trained in technical skills but some unfortunately leave university without the ethical and spiritual formation which would ensure that their insights and skills are used for the welfare of others and the support of the common good" (PCJP 2012, n. 86). Therefore, further developments should stimulate discussions in business and universities on how to contribute to a more complete formation of managers and future managers, educating them to be effective business leaders with high principles.

\section{References}

Abela, A. V. (2001). Profit and more: Catholic social teaching and the purpose of the firm. Journal of Business Ethics, 31(2), 107-116.

Abela, A. V. (2014). A catechism for business: Tough ethical questions and insights from catholic teaching. Washington, DC: Catholic University of America Press.

Abela, A. V., \& Murphy, P. E. (2008). Marketing with integrity: Ethics and the service-dominant logic for marketing. Journal of the Academy of Marketing Science, 36(1), 39-53.

Alexander, D. (Ed.). (1989). Christian spirituality: Five views of sanctification. Downers Grove, IL: IVP Academic.

Alford, H. J., \& Naughton, M. J. (2001). Managing as if faith mattered. Christian social principles in the modern organization. Notre Dame, IN: Notre Dame University Press.

Aquinas, T. (1981[1273]). Summa Theologiae. London: Burns Oates and Washbourne Ltd.

Attfield, R. (2001). Christianity. In D. Jamieson (Ed.), A companion to environmental philosophy (Chap. 7). Oxford: Blackwell.

Aumann, J. (1985). Christian spirituality in the catholic tradition. London: Bloomsbury.

Alves, A. A., \& Moreira, J. M. (2010). The school of Salamanca. New York, London: Continuum.

Alves, A. A., \& Moreira, J. M. (2013). Business ethics in the school of Salamanca. In C. Lüetge (Ed.), Handbook of the philosophical foundations of business ethics (pp. 207-225). Heidelberg: Springer.

Bay, D., McKeage, K., \& McKeage, J. (2010). An historical perspective on the interplay of Christian thought and business ethics. Business and Society, 49(4), 652-676.

Bayer, R. C. (1999). Capitalism and Christianity: The possibility of Christian personalism. Washington, DC: Georgetown University Press.

Benedict XVI (2009). Encyclical-Letter 'Caritas in veritate'. Available at www.vatica.va.

Bible, The Holy. (1966). New revised standard version (Catholic edition). Princeton, NJ: Scepter.
Booth, P. (Ed.). (2009). Christian perspectives on the financial crash. London: St. Paul Press.

Cameron, K., Dutton, J. E., \& Quinn, R. E. (Eds.). (2003). Positive organizational scholarship. San Francisco: Barrett.

Cameron, K. S., \& Spreitzer, G. M. (Eds.). (2012). Handbook of positive organizational scholarship. New York: Oxford University Press.

Catechism of the Catholic Church (2003). London: Random House. Available at: www.vatican.va/archive/ENG0015/_INDEX.HTM.

Cessario, R. (2013). Introduction to moral theology. Washington, DC: The Catholic University of America Press.

Chafuen, A. A. (1986). Christians for freedom: Late-scholastic economics. San Francisco: Ignatius Press.

Charles, R. (1998). Christian Social Witness and Teaching: The Catholic Tradition from Genesis to 'Centesiums annus' (2 vols.). Herefordshire: Gracewind.

Child, J. M., Jr. (1995). Ethics in business, faith at work. Minneapolis, $\mathrm{MN}$ : Fortress Press.

Cornwall, J. R., \& Naughton, M. J. (2003). Who is the good entrepreneur? An exploration within the catholic social tradition. Journal of Business Ethics, 44(1/2), 61-75.

Cortright, S. A., \& Naughton, M. J. (2002). Rethinking the purpose of business. Interdisciplinary essays from Catholic social tradition. Notre Dame, IN: Notre Dame University Press.

Crook, R. H. (2002). An introduction to Christian ethics. Upper Saddle River, NJ: Prentice Hall.

de Woot, P. (2013). Spirituality and business: A Christian viewpoint. An open letter to Christian leaders in times of urgency. Leeds: Greenleaf Publishing.

Delbecq, A. L. (1999). Christian spirituality and contemporary business leadership. Journal of Organizational Change Management, 12(4), 345-354.

Demuijnck, G. (2009). From an implicit Christian Corporate culture to a structured conception of corporate ethical responsibility in a retail company: A case-study in Hermeneutic ethics. Journal of Business Ethics, 84(Supl. 3), 387-404.

Elegido, J. M. (2003). Business ethics in the Christian tradition. Lagos: Spectrum Books Limited.

Enderle, G. (1997). In search of a common ethical ground: Corporate environmental responsibility from the perspective of Christian environmental stewardship. Journal of Business Ethics, 16(2), 173-181.

Faldetta, G. (2011). The logic of gift and gratuitousness in business relationships. Journal of Business Ethics, 100(1), 67-77.

Francis. (2015). Encyclical letter 'Laudato si', on the Catholic vision of the ecology. Available at www.vatican.va.

Fry, L. W. (2003). Toward a theory of spiritual leadership. Leadership Quarterly, 14(6), 693-727.

Giacalone, R., \& Jurkiewicz, C. (Eds.). (2003). Handbook of workplace spirituality and organizational performance. New York: Sharpe.

Gill, R. (Ed.). (2001). The Cambridge companion to Christian ethics. Cambridge, UK/New York: Cambridge University Press.

Grassl, W., \& Habisch, A. (2011). Ethics and economics: Towards a new humanistic synthesis for business. Journal of Business Ethics, 99(1), 37-49.

Greenleaf, R. K. (1970). The servant as leader. Indianapolis, IN: The Robert K. Greenleaf Center.

Greenleaf, R. K. (1977). Servant leadership. A journey into the nature of legitimate power and greatness. New York: Paulist Press.

Gustafson, A. (2013). Business for the Common good: A Christian vision for the marketplace. Business Ethics Quarterly, 23(1), 645-658.

Hill, A. D., \& Downers Grove, I. (1997). Just business: Christian ethics for the marketplace. Downers Grove, IL: InterVarsity Press. 
Hoffman, A. J., \& Sandelands, L. E. (2005). Getting right with nature: Anthropocentrism, ecocentrism, and theocentrism. Organization \& Environment, 18(2), 141-162.

Hoffmann-Holland, K. (2009). Ethics and human rights in a globalized world: An interdisciplinary and international approach. Berlin: Mohr Siebeck.

Ibrahim, N., Rue, L. W., McDougall, P. P., \& Greene, G. R. (1991). Characteristics and practices of 'Christian-Based' companies. Journal of Business Ethics, 10(2), 123-132.

Illanes, J. L. (2003). The sanctification of work. New York: Scepter.

Jackson, S. L. (2004). Integration in Christian ethical decisionmaking. Business \& Professional Ethics Journal, 23(4), 115-133.

John Paul II. (1981). Encyclical-letter 'Laborem exercerns' on human work. Available at www.vatican.va.

John Paul II. (1991). Encyclical-letter 'Centesimus annus' on the socioeconomic order. Available at www.vatican.va.

John Paul II. (1993). Encyclical-letter 'Veritatis Splendor', on Christian morals? Available at www.vatican.va.

John Paul II. (1998). Encyclical-letter 'Fides et ratio', on the relationship between faith and reason. Available at www. vatican.va.

John XXIII. (1961). Encyclical-letter 'Mater et Magistra' on the socioeconomic order. Available at www.vatican.va.

John XXIII. (1963). Encyclical-letter 'Pacem in Terris' on human rights and peace. Available at www.vatica.va.

Jones, D. (1997). Christian faith in the marketplace. Business Ethics Quarterly, 7(2), 149-150.

Kim, D., Fisher, D., \& McCalman, D. (2009). Modernism, Christianity, and business ethics: A worldview perspective. Journal of Business Ethics, 90(1), 115-121.

Lee, K.-H., McCann, D. P., \& Ching, M. (2003). Christ and business culture: A study of Christian executives in Hong Kong. Journal of Business Ethics, 43(1-2), 103-110.

Leo XIII. (1891). Encyclical-letter 'Rerum Novarum' on the labor and social order. Available at www.vatican.va.

Longenecker, J. G., McKinney, J. A., \& Moore, C. W. (2004). Religious intensity, evangelical Christianity, and business ethics: An empirical study. Journal of Business Ethics, 55(3), 373-386.

Lower, M. L. (2008). Christian anthropology and the theory of the firm. Journal of Catholic Social Thought, 5(2), 413-435.

Lüetge, C. (Ed.) (2008), Handbook of the Philosophical Foundations of Business Ethics (3 vols.). Heidelberg, Germany: Springer.

Lynn, M., Naughton, M., \& VanderVeen, S. (2009). Faith at work scale (FWS): Justification, development, and validation of a measure of Judeo-Christian religion in the workplace. Journal of Business Ethics, 85(2), 227-243.

Magill, G. (1992). Theology in business ethics: Appealing to the religious imagination. Journal of Business Ethics, 11(2), 129135

May, W. E. (2003). An introduction to moral theology. Huntington, IN: Our Sunday Visitor.

McCann, D. (2011). The principle of gratuitousness: Opportunities and challenges for business in 'Caritas in Veritate'. Journal of Business Ethics, 100(1), 55-66.

McDaniel, C. A. Jr. (2011). Theology of the "real economy": Christian economic ethics in an age of financialization. Journal of Religion and Business Ethics, 2(2), Art. 1. Available at: http:// via.library.depaul.edu/jrbe/vol2/iss2/1.

McGrath, A. E. (1999). Christian spirituality. An introduction. Oxford: Blackwell.

Melé, D. (1999). Early business in Spain: The Salamanca school (1526-1614). Journal of Business Ethics, 22, 175-189.

Melé, D. (2005). Exploring the principle of subsidiarity in organizational forms. Journal of Business Ethics, 60(3), 293-305.

Melé, D. (2008). Christian ethics. In R. W. Kolb (Ed.), Encyclopedia of business ethics and society (pp. 311-313). Los Angeles: Sage.

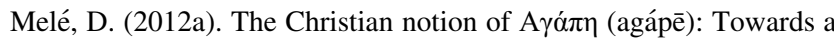
more complete view of business ethics. In G. P. Prastacos, F. Wang, \& K. E. Soderquist (Eds.), Leadership through the Classics. Learning Management and Leadership from Ancient East and West Philosophy (pp. 79-91). Heidelberg: Springer.

Melé, D. (2012b). The firm as a "community of persons": A pillar of humanistic business ethos. Journal of Business Ethics, 106(1), 89-101.

Melé, D. (2013). Scholastic thought and business ethics: An overview. In C. Lüetge (Ed.), Handbook of the philosophical foundations of business ethics (pp. 133-158). Heidelberg: Springer.

Melé, D. (2016). Re-thinking capitalism: What can we learn from scholasticism? Journal of Business Ethics, 133(2), 293-304.

Melé, D. (2016). Virtues, values, and principles in Catholic social teaching. In A. J. Sison \& I. Ferrero (Eds.), Handbook of virtue ethics in business and management. Heidelberg: Springer. doi:10.1007/978-94-007-6729-4_9-3.

Melé, D., \& Dierksmeier, C. (Eds.). (2012). Human development in business. Values and humanistic management in the in the encyclical 'Caritas in Veritate'. New York: Palgrave MacMillan.

Melé, D., \& Schlag, M. (Eds.). (2015). Humanism in economics and business. Perspectives of the Catholic social tradition. Dordrecht, Heidelberg: Springer.

Naughton, M. (1992). The good stewards: Practical applications of the papal social vision of work. Lanham, MD: University Press of America.

Naughton, M. J. (2006). The corporation as a community of work: Understanding the firm within the Catholic social tradition. Ave Maria Law Review, 4(1), 33-75.

Naughton, M. J., Alford, H. J., \& Brady, B. (1995). The common good and the purpose of the firm. Journal of Human Values, 1(2), 221-237.

Naughton, M. J., Buckeye, J. G., Goodpaster, K. E., \& Maines, T. D. (2015). Respect in action. Applying subsidiarity in business. St. Paul, MI: UNIAPAC-University of St. Thomas.

Naughton, M. J., \& Cornwall, J. R. (2006). The virtue of courage in entrepreneurship engaging the Catholic social tradition. Business Ethics Quarterly, 16(1), 69-93.

Naughton, M., \& Cornwall, J. R. (2009). Culture as the basis of the good entrepreneur. Journal of Religion \& Business Ethics, 1(1), $1-13$.

Naughton, M., \& Specht, D. (2011). Leading wisely in difficult times: Three cases of faith and business. New York: Paulist Press.

Novak, M. (1998). The Judeo-Christian foundation of human dignity. Journal of Markets \& Morality, 1(2), 107-121.

Parris, D. L., \& Peachey, J. W. (2013). A systematic literature review of servant leadership theory in organizational contexts. Journal of Business Ethics, 113, 377-393.

Paul VI. (1967). Encyclical-letter 'Populorum Progressio' on development of people. Available at www.vatican.va.

PCJP (Pontificium Consilium Justice and Peace). (2004). Compendium of the social doctrine of the Church. Città del Vaticano: Libreria Editrice Vaticana. Available at http://www.vatican.va/ roman_curia/pontifical_councils/justpeace/documents/rc_pc_just peace_doc_20060526_compendio-dott-soc_en.html.

PCJP (Pontificium Consilium Justice and Peace). (2012). Vocation of the business leader. A reflection. Available at http://www. iustitiaetpax.va/content/giustiziaepace/en/archivio/pubblica zioni/vocation-of-the-business-leader-a-reflection-.html.

Pinckaers, S. (1995). The sources of Christian ethics (Original: Les sources de la morale crètinne, University Press Fribourg, 1985). Washington, DC: The Catholic University of America.

Pius XI. (1931). Encyclical Letter 'Quadragesimo anno'. Available at www.vatican.va.

Ratzinger, J. (1975). The church's teaching. Authority-faith-morals. In H. Schürmann, J. Ratzinger, \& H. V. Balthasar (Eds.), 
Principles of Christian morality (pp. 45-73). San Francisco: Ignatius Press.

Scheiders, S. M. (1989). Spirituality in the academy. Theological Studies, 50(4), 676-697.

Schlag, M. (2013). Economic and business ethics in select Italian scholastics (ca. 1200-1450). In C. Lüetge (Ed.), Handbook of the philosophical foundations of business ethics (pp. 178-205). Heidelberg: Springer.

Scorgie, G. G., Chan, S., Smith, G. T., \& Smith, James D. I. (Eds.). (2011). Dictionary of Christian spirituality. Grand Rapids, MI: Zondervan.
Tullberg, J. (2012). The golden rule of benevolence versus the silver rule of reciprocity. Journal of Religion and Business Ethics, 3(1), art. 2. Available at: http://via.library.depaul.edu/jrbe/vol3/iss1/2.

Wadell, P. J. (1991). The primacy of love: An introduction to the ethics of Thomas Aquinas. New York: Paulist Press.

Wogaman, J. P. (1993). Christian ethics: A historical introduction. Louisville, KY: Westminster/John Knox Press.

Wyszynski, S. (1995). All you who labor: Work and the sanctification of daily life. Browntown, CT: Sophia Institute Press. 